\title{
Effect of Some Preceded Peanut Cultivars on Wheat Yield and Agro - Economic Feasibility Under Two Cropping Systems in Sandy Soil
}

\author{
Abdel-Galil Mohamed Abdel-Galil ${ }^{1}$, Sherif Ibrahim Abdel-Wahab ${ }^{1}$ \& Tamer Ibrahim Abdel-Wahab ${ }^{1}$ \\ ${ }^{1}$ Crop Intensification Research Department, Field Crops Research Institute, Agricultural Research Center, Giza, \\ Egypt \\ Correspondence: Abdel-Galil Mohamed Abdel-Galil, Crop Intensification Research Department, Field Crops \\ Research Institute, Agricultural Research Center, Giza, Egypt. E-mail: abdelgalil_abdelgalil@yahoo.com
}

Received: December 24, $2014 \quad$ Accepted: March 18, 2015 Online Published: March 23, 2015
$\begin{aligned} & \text { doi:10.5539/sar.v4n2p47 } \\ & \text { URL: http://dx.doi.org/10.5539/sar.v4n2p47 }\end{aligned}$

\begin{abstract}
The cropping system is an approach to help farmer in decision making to remain sustainable in an ever-changing agricultural environment. A two-year study was carried out at Ismailia Agricultural Experiments and Research Station, ARC, Ismailia governorate, Egypt during 2011/2012 and 2012/2013 seasons to study the effect of preceded peanut cultivars on yield and profitability of wheat under conventional and inetsnive cropping systems in sandy soil. This experiment included six treatments which were the combinations of three peanut cultivars (Giza 4, Giza 5 and Ismailia 1) as preceding cultivars in the summer season and two cropping systems (conventional and intensive). A split plot design with three replications was used. The results indicated that peanut $\mathrm{cv}$. Ismailia 1 increased available soil nitrogen $(\mathrm{N})$ content which affected positively number of grains per spike and grain weight per spike and finally the economic yield. Growing fahl berseem in transition period between peanut and wheat enhanced available soil $\mathrm{N}$ content that increased grain yield per ha by about 1.00 percent as compared with those of conventional cropping system. Accordingly, intensive cropping system increased wheat grain yield and its attributes as compared with conventional cropping system. Peanut cultivars $\times$ cropping systems interaction had a significant effect on available soil $\mathrm{N}$ content and all the studied wheat traits except number of spikes $/ \mathrm{m}^{2}$. Intensive cropping system increased total and net returns as compared with conventional cropping system. The Egyptian farmers could achieve an increase in their income by US\$755.9 per ha when using intensive cropping system which included peanut cv. Ismailia 1
\end{abstract}

Keywords: peanut cultivars, fahl berseem, wheat, cropping systems, economic return

\section{Introduction}

For the last several years in Egypt, special attention has been directed towards reclaiming desert soils, sandy or calcareous in nature. If Egyptian agricultural production must be intensified, ways of making maximum use of sandy soils must be pursued without soil degradation and pollution, which are often the result of intensive mineral $\mathrm{N}$ fertilizer application. The environmental problems associated with excessive use of $\mathrm{N}$ fertilizer is now a contentious issue and must be increasing number of crops per year outside the Nile Valley and Delta without soil degradation and pollution by using biological nitrogen fixation (BNF). However, BNF in legume nodules is severely affected by different environmental constraints under these soils conditions. Legumes contribute to a diversification of cropping systems and as $\mathrm{N}_{2}$-fixing plant in sandy soil; it can improve the exchanges of nutrients and water in a sandy soil where plant roots thrive. $\mathrm{N}$ is the most important nutrient element required for crop production especially for cereals, which have been reported to dominate cultivated land in the world (Myers, 1988). Accordingly, BNF is a convenient source of $\mathrm{N}$ for sequential crop planting in Egyptian agriculture; its use is ultimately governed and regulated by economic and environmental considerations under sandy soils conditions.

Cropping index refers to the times of sequential crop planting in the same arable land in one year, usually defined as the ratio of the total seeding area to the arable land area (Liu, 2013). Wheat (Triticum aestivum L.) is the most important cereal crop because it is the staple food of the Egyptian people. Increasing wheat productivity in sandy soils is one of the main targets for crop intensification scientists where grain protein concentration and composition are major determinants of grain nutritional value (Feil, 1997) but $\mathrm{N}$ requires careful management when used for crop production on sandy soils because of the high potential for leaching losses of nitrate through 
these soils. For that should increase the number of crops per year with decreasing mineral $\mathrm{N}$ fertilizer use by BNF.

Several of the nutrients that are essential for growth of plants or bacteria play specific roles in symbiotic $\mathrm{N}_{2}$-fixation through their effects on nodulation and the $\mathrm{N}_{2}$ - fixation process (O'Hara, 2001). It has been reported that the net benefits of legumes are often equivalent to the addition of $50-100 \mathrm{~kg} \mathrm{~N}$ per ha as fertilizer (Phoomthaisong et al., 2003), especially $\mathrm{N}$ deficiency is one of the major yield limiting factors for cereals (Shah et al., 2003). BNF occurs mainly through symbiotic association of legumes and some woody species with certain $\mathrm{N}_{2}$-fixing microorganisms that convert elemental $\mathrm{N}$ into ammonia (Shiferaw et al., 2004).

On the other hand, peanut (Arachis hypogaea L.) is an important oil and protein crop; it contains about 40-50\% oil, $25-30 \%$ protein, $20 \%$ carbohydrates and $5 \%$ fiber and ash, and makes a substantial contribution to human nutrition (Fageria et al., 1997). Peanut genotypes were differed in pod number per plant because it had good N fixing ability, and thus fixed $\mathrm{N}$ could contribute to agronomic performance in larger extent (Pimratch et al., 2004). The two local cultivars of peanut (Giza 4 and Giza 5) showed significant variation in most of the studied characters under sandy soil conditions (Abd El-Maksoud, 2008). Also, El-Saady et al. (2014) concluded that the differential benefits of peanut cultivars from available nutrients in soil, might be attributed to the variation in their root system volumes, as well as, their root exudations.

Accordingly, the cropping system adopted by the farmer in these soils must be physically viable, sustainable, less exhaustive acceptable to farming community and most important thing is that it should be economical. Peanut wheat crop sequence is a conventional crop system in Ismailia governorate. Sandy soils requires proper management to offer optimum productivity of any cultivated crop, especially for the studied cropping systems here, which has been peanut followed by wheat where peanut and wheat cultivated areas reached about 44,653 and 251,759 thousands ha in new lands in 2012 with an average yields of 3.22 and 5.79 tons per ha, respectively, (Bulletin of Statistical Cost Production and Net Return, 2013 and 2014).

Although legume-cereal sequence increased biomass and grain yield of subsequent wheat (Hayat et al., 2008), however, this necessitates the inclusion of leguminous fodder crops as berseem (Trifolium alexandrinum L.), which capable of supplying green fodder after 70 days from sowing by one cut "fahl", after peanut harvest and before wheat sowing in our cropping system (peanut - fahl berseem - wheat) as these have the ability of enriching the $\mathrm{N}$ content of these soils by fixing $\mathrm{N}$ from the air, in addition to improving the productivity of soil. Some legumes are better at fixing $\mathrm{N}$ than others (Lindemann \& Glover, 2013). So, the present study was, therefore, conducted to study the effect of preceded peanut cultivars on yield and profitability of wheat under conventional and intensive cropping systems in sandy soil.

\section{Method}

A two-year study was carried out at Ismailia Agricultural Experiments and Research Station, A.R.C., Ismailia governorate (Lat. 30 35' 30" N, Long. 32 ${ }^{\circ} 14^{\prime}$ 50" E, 10 m a.s.l.), Egypt during 2011/2012 and 2012/2013 seasons to study the effect of preceded peanut cultivars on yield and profitability of wheat under conventional and intensive cropping systems in sandy soil. Mechanical and chemical analyses of the soil $(0-20 \mathrm{~cm})$ were done by General Organization for Agricultural Equalization Fund, Agricultural Research Center, Giza, Egypt. The experimental soil had 12.16 percent clay, 2.20 percent silt and 85.64 percent sand, and loamy sand texture. Available soil $\mathrm{N}$ content was 5.0 percent in the first season and 10.0 percent in the second season before sowing peanut seeds $(0$-time). This experiment included six treatments which were the combinations of three peanut cultivars (Giza 4, Giza 5 and Ismailia 1) as preceding crops in the summer season and two cropping systems (conventional and intensive). The cropping systems were illustrated in Figure (1) as follows:

Conventional cropping system (peanut / wheat crop sequence): planting peanut in the summer season then planting wheat in the winter season (pattern I).

- Intensive cropping system (peanut / fahl berseem / wheat crop sequence): planting peanut in the summer season then planting fahl berseem in the autumn season then planting wheat in the winter season (pattern II).

Wheat cultivar Sakha 94 was used. Peanut cultivars were sown on May $2^{\text {nd }}$ and $8^{\text {th }}$ at 2011 and 2012 summer seasons, respectively, while, fahl berseem cv. Gemmiza 1 was sown on September $11^{\text {th }}$ and $13^{\text {th }}$ at 2011 and 2012 seasons, while, wheat was sown on November $30^{\text {th }}$ and $28^{\text {th }}$ at 2011/2012 and 2012/2013 winter seasons, respectively. Peanut cultivars were uprooted on September $7^{\text {th }}$ and $9^{\text {th }}$ at 2011 and 2012 summer seasons, while, fahl berseem was cut on November $23^{\text {rd }}$ and $21^{\text {st }}$ at 2011 and 2012 winter season and wheat was harvested on May $6^{\text {th }}$ and $9^{\text {th }}$ at 2012 and 2013 summer season, respectively.

In the two seasons, peanut and berseem seeds were inoculated by Bradyrhizobium and Rhizobium trifolii, 
respectively, before seeding it. Peanut was seeded at $10 \mathrm{~cm}$ apart between hills with one plant per hill after thinning. In the two winter seasons, wheat grains and berseem seeds were drilled at the rate of 166.6 and $59.5 \mathrm{~kg}$ per ha, respectively. Normal practices for growing all crops were used as recommended in the area. Sprinkler irrigation was the irrigation system in the area. Calcium super phosphate $\left(15.5 \% \mathrm{P}_{2} \mathrm{O}_{5}\right)$ at rate of $476 \mathrm{~kg}$ per ha and potassium sulfate $\left(48.0 \% \mathrm{~K}_{2} \mathrm{O}\right)$ at rate of $238 \mathrm{~kg}$ per ha were applied during soil preparation for sowing peanut in the summer season. The previous rates of calcium super phosphate and potassium sulfate were also applied during soil preparation for sowing wheat in the winter season. Calcium sulfate at rate of $1190 \mathrm{~kg}$ per ha was applied for peanut after 35-40 days from peanut sowing. Mineral $\mathrm{N}$ fertilizer at rates of 107.1 and $238.0 \mathrm{~kg}$ per ha were applied during different growth stages of peanut and wheat, respectively. A split plot design replicated thrice was used. Peanut cultivars were randomly assigned to the main plots, while the cropping systems were allotted in subplots. Each plot contained five ridges, each ridge was $3.0 \mathrm{~m}$ in length, $0.6 \mathrm{~m}$ in width and the plot area was $9 \mathrm{~m}^{2}$.

\section{Pattern I}

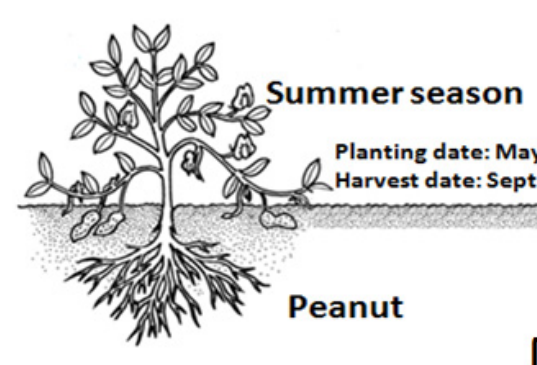

Conventional cropping system

Pattern II

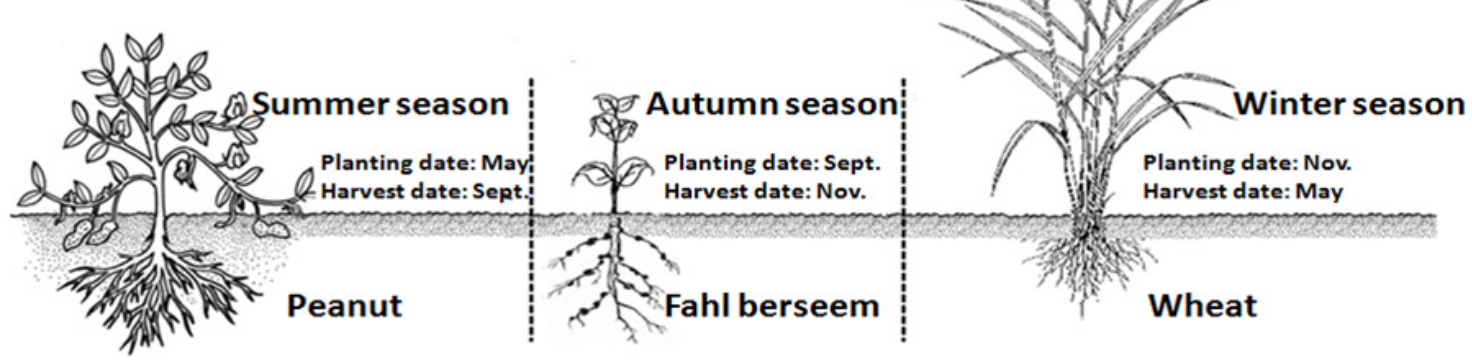

Intensive cropping system

Figure 1. Conventional and intensive cropping systems under sandy soil conditions

\subsection{The Studied Traits}

\subsubsection{Available Soil N Content}

Soil samples were collected after harvest of peanut cultivars and after cutting fahlberseem by auger at the depth of $0-20 \mathrm{~cm}$ in the two growing seasons. These samples were air-dried, crushed, and sieved by $2-\mathrm{mm}$ sieve and preserved for the chemical analysis. These analyses were performed in General Organization for Agricultural Equalization Fund, Agricultural Research Center, Giza, Egypt.

\subsubsection{Wheat Yield and Its Attributes}

These traits were measured at harvest on ten guarded plants of wheat from each plot: number of spikes per $\mathrm{m}^{2}$, spike weight $(\mathrm{g})$, number of grains per spike, 1000 - grain weight $(\mathrm{g})$ and grain protein content (\%). Protein percentage in wheat grains was determined by the improved kjeldahl method of (A.O.A.C., 2000) modified by distilling the ammonia into saturated boric solution and titration was carried out by using standard acid. Grain 
protein content was calculated by multiplying the total nitrogen by 5.7. These analyses were performed in General Organization for Agricultural Equalization Fund, Agricultural Research Center, Giza, Egypt. Grain yield of wheat per ha (ton) was recorded on the basis of experimental plot area by harvesting of all plants of each plot. In addition to estimate pod yield of peanut per ha (ton) and forage yield of berseem per ha (ton) on the basis of experimental plot area.

\subsubsection{Economic Return}

Peanut pods and wheat grains prices presented by (Bulletin of Statistical Cost Production and Net Return, 2013 and 2014) were used, while forage yield of berseem price presented by market price (2012) was used. Net return was calculated as follows: Net return $=$ total costs - total return according to cropping system.

\subsection{Statistical Manipulation}

Analysis of variance of the obtained results of each season was performed. The measured variables were analyzed by ANOVA using MSTATC statistical package (Freed, 1991). Mean comparisons were done using least significant differences (L.S.D) method at $5 \%$ levels of probability to compare differences between the means (Gomez \& Gomez, 1984).

\section{Results}

\subsection{Available Soil N Content}

\subsubsection{Peanut Cultivars}

Available soil $\mathrm{N}$ content was differed significantly after uprooting of peanut cultivars in combined data across 2011/2012 and 2012/2013 seasons (Table 1), where peanut cv. Ismailia 1 increased $(\mathrm{P} \leq 0.05)$ available soil $\mathrm{N}$ content by 60.37 and 46.77 percent as compared with available soil $\mathrm{N}$ content after uprooting of peanut cv. Giza 4 in the first and second season, respectively, while this increase was 16.43 and 13.75 percent as compared with available soil $\mathrm{N}$ content after uprooting of peanut cv. Giza 5 in the first and second seasons, respectively.

Table 1. Effect of peanut cultivars, cropping systems and their interaction on available soil $\mathrm{N}$ content in 2011/2012 and 2012/2013 seasons

\begin{tabular}{lcccccc}
\hline \multirow{2}{*}{$\begin{array}{l}\text { Peanut } \\
\text { cultivars }\end{array}$} & \multicolumn{5}{c}{ Growing season } \\
\cline { 2 - 7 } & \multicolumn{3}{c}{ Available soil N content (ppm) } & \multicolumn{3}{c}{ Available soil N content (ppm) } \\
\cline { 2 - 7 } & $\mathrm{C}$ & $\mathrm{I}$ & Mean & $\mathrm{C}$ & $\mathrm{I}$ & Mean \\
\cline { 2 - 7 } & 18.0 & 35.0 & 26.5 & 23.0 & 39.0 & 31.0 \\
\hline Giza 4 & 28.0 & 45.0 & 36.5 & 32.0 & 48.0 & 40.0 \\
\hline Giza 5 & 35.0 & 50.0 & 42.5 & 41.0 & 50.0 & 45.5 \\
\hline Ismailia 1 & 27.0 & 43.3 & 35.1 & 32.0 & 45.6 & 38.8 \\
\hline Mean & & 8.13 & & & 4.36 \\
\hline L.S.D. at 0.05 Peanut cultivars & & 5.78 & & & 2.91 \\
L.S.D. at 0.05 Cropping systems & & 11.24 & & & 7.27 \\
L.S.D. at 0.05 Interaction & &
\end{tabular}

Note. $\mathrm{C}=$ Conventional cropping system, I = Intensive cropping system.

\subsubsection{Cropping Systems}

Available soil $\mathrm{N}$ content was affected significantly by the cropping systems in the two growing seasons (Table 1). Growing fahl berseem during the transition period between peanut and wheat increased $(P \leq 0.05)$ available soil $\mathrm{N}$ content by 60.37 percent in the first season and 42.5 percent in the second season.

\subsubsection{The Interaction Between Peanut Cultivars and Cropping Systems}

Available soil $\mathrm{N}$ content was affected significantly by the interaction between peanut cultivars and the cropping systems in the two growing seasons (Table 1). The highest available soil $\mathrm{N}$ content was obtained by growing fahl berseem during the transition period between peanut cv. Ismailia 1 and wheat; meanwhile, the lower available soil $\mathrm{N}$ content was obtained by uprooting of peanut $\mathrm{cv}$. Giza 4 as compared with the other treatments. 


\subsection{Wheat Yield and Its Attributes}

\subsubsection{Peanut Cultivars}

Number of spikes per $\mathrm{m}^{2}$, spike weight, number of grains per spike, 1000 - grain weight, grain yield per ha and grain protein content were affected significantly by peanut cultivars in the combined data across 2011/2012 and 2012/2013 seasons (Table 2). Growing wheat after peanut cv. Ismailia 1 caused significant increase in number of spikes per $\mathrm{m}^{2}$, spike weight, number of grains per spike, 1000 - grain weight, grain yield per ha and grain protein content in comparison with growing wheat after the other peanut cultivars. Growing wheat after peanut cv. Ismailia 1 increased $(P \leq 0.05)$ grain yield per ha by 1.16 and 5.67 percent as compared with those grown after peanut cv. Giza 5 and Giza 4, respectively.

Table 2. Effect of peanut cultivars, cropping systems and their interaction on yield and its attributes of wheat, combined data across 2011/2012 and 2012/2013 seasons

\begin{tabular}{|c|c|c|c|c|c|c|c|c|c|}
\hline \multirow[t]{2}{*}{ Peanut cultivars } & \multicolumn{3}{|c|}{$\begin{array}{l}\text { Spikes } / \mathrm{m}^{2} \\
\text { (no.) }\end{array}$} & \multicolumn{3}{|c|}{$\begin{array}{l}\text { Spike weight } \\
(\mathrm{g})\end{array}$} & \multicolumn{3}{|c|}{$\begin{array}{l}\text { Grains/spike } \\
\text { (no.) }\end{array}$} \\
\hline & $\mathrm{C}$ & $\mathrm{I}$ & Mean & $\mathrm{C}$ & $\mathrm{I}$ & Mean & $\mathrm{C}$ & I & Mean \\
\hline Giza 4 & 367.66 & 375.66 & 371.66 & 1.86 & 1.89 & 1.87 & 37.51 & 37.84 & 37.68 \\
\hline Giza 5 & 384.00 & 396.66 & 390.33 & 1.98 & 2.06 & 2.02 & 39.94 & 40.16 & 40.05 \\
\hline Ismailia 1 & 387.33 & 398.00 & 392.66 & 2.06 & 2.09 & 2.07 & 40.23 & 40.52 & 40.37 \\
\hline Mean & 379.66 & 390.11 & 384.88 & 1.96 & 2.01 & 1.98 & 39.23 & 39.51 & 39.37 \\
\hline \multicolumn{3}{|c|}{ L.S.D. at 0.05 Peanut cultivars } & 13.47 & & & 0.07 & & & 0.36 \\
\hline \multicolumn{3}{|c|}{ L.S.D. at 0.05 Cropping systems } & 6.02 & & & 0.04 & & & 0.19 \\
\hline \multicolumn{3}{|c|}{ L.S.D. at 0.05 Interaction } & N.S. & & & 0.11 & & & 0.52 \\
\hline \multirow[t]{2}{*}{ Peanut cultivars } & \multicolumn{3}{|c|}{$\begin{array}{c}1000 \text { - grain weight } \\
\text { (g) }\end{array}$} & \multicolumn{3}{|c|}{$\begin{array}{l}\text { Grain yield } \\
\text { (ton/ha) }\end{array}$} & \multicolumn{3}{|c|}{$\begin{array}{l}\text { Grain protein } \\
\text { content (\%) }\end{array}$} \\
\hline & $\mathrm{C}$ & I & Mean & $\mathrm{C}$ & $\mathrm{I}$ & Mean & $\mathrm{C}$ & I & Mean \\
\hline Giza 4 & 38.92 & 39.08 & 39.00 & 4.90 & 4.95 & 4.93 & 8.26 & 8.34 & 8.30 \\
\hline Giza 5 & 40.24 & 40.50 & 40.37 & 5.13 & 5.17 & 5.15 & 8.60 & 8.69 & 8.64 \\
\hline Ismailia 1 & 40.46 & 40.62 & 40.54 & 5.18 & 5.24 & 5.21 & 8.70 & 8.76 & 8.73 \\
\hline Mean & 39.87 & 40.07 & 39.97 & 5.07 & 5.12 & 5.09 & 8.52 & 8.59 & 8.55 \\
\hline \multicolumn{3}{|c|}{ L.S.D. at 0.05 Peanut cultivars } & 0.17 & & & 0.07 & & & 0.10 \\
\hline \multicolumn{3}{|c|}{ L.S.D. at 0.05 Cropping systems } & 0.19 & & & 0.03 & & & 0.05 \\
\hline \multicolumn{3}{|c|}{ L.S.D. at 0.05 Interaction } & 0.22 & & & 0.09 & & & 0.12 \\
\hline
\end{tabular}

Note. $\mathrm{C}=$ Conventional cropping system, I = Intensive cropping system.

\subsubsection{Cropping Systems}

Number of spikes per $\mathrm{m}^{2}$, spike weight, number of grains per spike, 1000 - grain weight, grain yield per ha and grain protein content were affected significantly by the cropping systems in combined data across 2011/2012 and 2012/2013 seasons (Table 2). Intensive cropping system caused significant increase $(P \leq 0.05)$ in number of spikes per $\mathrm{m}^{2}$, number of grains per spike, spike weight, 1000 - grain weight, grain yield per ha and grain protein content in comparison with conventional cropping system. Intensive cropping system increased grain yield per ha by about 1.00 percent as compared with those of conventional cropping system.

\subsubsection{The Interaction Between Peanut Cultivars and Cropping Systems}

Number of grains per spike, spike weight, 1000 - grain weight, grain yield per ha and grain protein content were affected significantly by the interaction between peanut cultivars and cropping systems except number of spikes per $\mathrm{m}^{2}$ in the combined data across 2011/2012 and 2012/2013 seasons (Table 2). The highest values of spike weight, number of grains per spike, 1000 - grain weight, grain yield per ha and grain protein content were 
obtained by growing fahl berseem during the transition period between peanut cv. Ismailia 1 and wheat; meanwhile, the lowest values of spike weight, number of grains per spike, 1000 - grain weight, grain yield per ha and grain protein content were obtained by uprooting of peanut cv. Giza 4 as compared with the other treatments.

\subsection{Economic Return}

Intensive cropping system increased total and net returns by 35.23 and 42.09 percent, respectively, as compared with the other one (Table 3). Net return was varied between treatments from US\$1530.9 (conventional cropping system by using peanut $\mathrm{cv}$. Giza 4) to US\$2739.8 (intensive cropping system by using peanut cv. Ismailia 1) per ha. Intensive cropping system by using peanut cv. Ismailia 1 increased net return by 38.10 percent as compared with conventional cropping system by using peanut cv. Ismailia 1. It is noticed that growing leguminous crop after peanut cv. Ismailia 1 is more profitable for Egyptian farmers.

Table 3. Economic return as affected by peanut cultivars, cropping systems and their interaction, combined data across 2011/2012 and 2012/2013 seasons

Treatments Yield per ha (ton)

\begin{tabular}{|c|c|c|c|c|c|}
\hline & & Peanut & \multicolumn{2}{|c|}{ Fahl berseem } & Wheat \\
\hline \multicolumn{6}{|c|}{ Conventional cropping system } \\
\hline \multicolumn{2}{|l|}{ Peanut cv. Giza 4} & 2.45 & \multicolumn{2}{|l|}{--- } & 4.90 \\
\hline \multicolumn{2}{|l|}{ Peanut cv. Giza 5} & 2.59 & \multicolumn{2}{|l|}{$\begin{array}{l}-- \\
-1\end{array}$} & 5.13 \\
\hline \multicolumn{2}{|l|}{ Peanut cv. Ismailia 1} & 2.78 & \multicolumn{2}{|l|}{---} & 5.18 \\
\hline \multicolumn{2}{|l|}{ Mean } & 2.60 & \multicolumn{2}{|l|}{---} & 5.07 \\
\hline \multicolumn{6}{|c|}{ Intensive cropping system } \\
\hline \multicolumn{2}{|l|}{ Peanut cv. Giza 4} & 2.45 & \multicolumn{2}{|l|}{22.8} & 4.95 \\
\hline \multicolumn{2}{|l|}{ Peanut cv. Giza 5} & 2.59 & \multicolumn{2}{|l|}{23.3} & 5.17 \\
\hline \multicolumn{2}{|l|}{ Peanut cv. Ismailia 1} & 2.78 & \multicolumn{2}{|l|}{23.3} & 5.24 \\
\hline Mean & & 2.60 & \multicolumn{2}{|l|}{23.1} & 5.12 \\
\hline \multirow[t]{3}{*}{ Treatments } & \multicolumn{5}{|c|}{ Economic return (US\$) per ha } \\
\hline & \multirow{2}{*}{$\begin{array}{l}\text { Total } \\
\text { return }\end{array}$} & \multicolumn{3}{|c|}{ Costs } & \multirow{2}{*}{$\begin{array}{c}\text { Net } \\
\text { return }\end{array}$} \\
\hline & & Peanut & Fahl berseem & Wheat & \\
\hline \multicolumn{6}{|c|}{ Conventional cropping system } \\
\hline Peanut cv. Giza 4 & 4402.2 & 1366.8 & --- & 1504.5 & 1530.9 \\
\hline Peanut cv. Giza 5 & 4634.8 & 1366.8 & --- & 1504.5 & 1763.5 \\
\hline Peanut cv. Ismailia 1 & 4855.2 & 1366.8 & --- & 1504.5 & 1983.9 \\
\hline Mean & 4630.7 & 1366.8 & --- & 1504.5 & 1759.4 \\
\hline \multicolumn{6}{|c|}{ Intensive cropping system } \\
\hline Peanut cv. Giza 4 & 6010.2 & 1366.8 & 890.8 & 1504.5 & 2248.1 \\
\hline Peanut cv. Giza 5 & 6274.5 & 1366.8 & 890.8 & 1504.5 & 2512.4 \\
\hline Peanut cv. Ismailia 1 & 6501.9 & 1366.8 & 890.8 & 1504.5 & 2739.8 \\
\hline Mean & 6262.2 & 1366.8 & 890.8 & 1504.5 & 2500.1 \\
\hline
\end{tabular}

Note. Prices of main products are that of 2012: Peanut pods: US\$ 1060.95 per ton, Berseem green forage: US\$ 69.71 per ton, Wheat grains: US\$ 368.0 per ton. 


\section{Discussion}

It seems that peanut cultivars had different ability of $\mathrm{N}$ fixation process under sandy soil conditions that led to different available soil $\mathrm{N}$ content after uprooting of these cultivars. These results may be a result of a mix of living rhizobia and dead peanut cultivars near the sandy soil surface where the populations of rhizobia is considered as a biological pool affect soil $\mathrm{N}$ dynamic. These results are in accordance with those obtained by Toomsan et al. (1995) who reported that there was a net contribution of $\mathrm{N}$ from $\mathrm{N}_{2}$-fixing varieties of groundnut in all cases ranged from 13-100 $\mathrm{kg} \mathrm{N} \mathrm{ha}^{-1}$ when legume stover was returned to the soil. Also, Baldwin (2006) reported that the populations of microorganisms that make up the biological pool are the driving forces in soil nutrient dynamics. Together they also play a key role in building a soil structure that both retains and freely exchanges nutrients and water-a soil where plant roots thrive.

Naturally, available soil $\mathrm{N}$ content that is absorbed by peanut would be exhausted without replenishment from other $\mathrm{N}$ sources such as atmospheric $\mathrm{N}$ or more stable soil $\mathrm{N}$. Accordingly, these results may be attributed to these cultivars have different ability of $\mathrm{N}$ fixation under sandy soil conditions. The main genetic potential for improving the amount of BNF in these cultivars depends upon factors that promote high photosynthetic productivity and efficient $\mathrm{N}$-use with effective rhizobial associations under sandy soil conditions. $\mathrm{N}$ fixing ability in peanut varies widely, depending on peanut genotypes (Nambiar et al., 1983). It has been reported that various cultivars of grain legumes show significant differences regarding their ability to support BNF (Hardarson, 1993). At the time of pod fill, nodules on annual legumes generally lose their ability to fix $\mathrm{N}$, because the plant feeds the developing seed rather than the nodule (Lindemann \& Glover, 2013).

So, it may be possible that root system of peanut cv. Ismailia 1 developed and absorbed more moisture and nutrients from sandy soil as elongated roots cover more surface area in the experimental soil and as such fixed substantial quantity of $\mathrm{N}$ through nodulation on roots in comparison with peanut cv. Giza 4 and Giza 5 . Consequently, peanut $\mathrm{cv}$. Ismailia 1 had the highest assimilate partitioning that reflected on pod yield per ha in comparison with the other two cultivars (Figure 2), especially peanut cv. Giza 5 was superior than peanut cv. Giza 4 in pod yield kg per unit area (Asfour et al., 2009). Such effect was expected because of soil $\mathrm{N}$ content among these cultivars were differed in the experimental soil (Table 1), where there was significant correlation between fixed $\mathrm{N}$ and biomass production (Dinh et al., 2013).

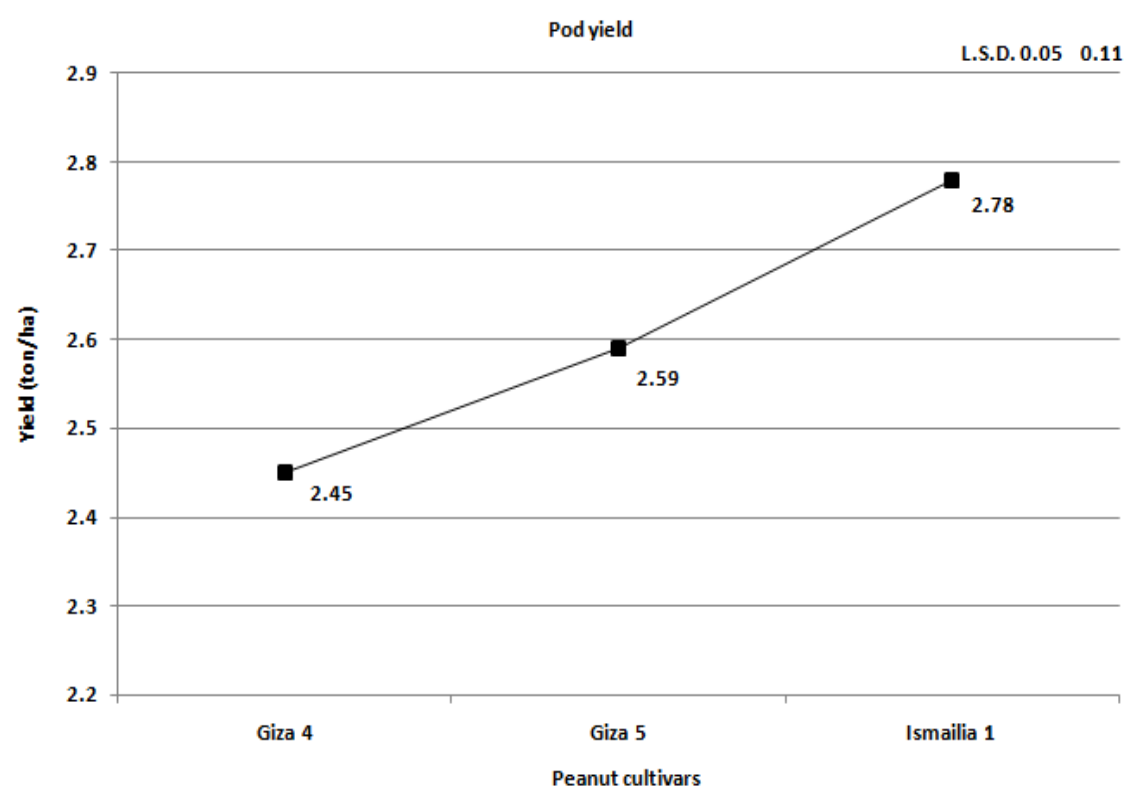

Figure 2. Pod yield of peanut cultivars which grown in sandy soil, combined data across 2011/2012 and 2012/2013 seasons

In view of the above, peanut cv. Ismailia 1 had the highest $\mathrm{N}$ fixing ability that led to positive residual effect on available soil $\mathrm{N}$ content and reflected on the yield attributes of wheat in comparison with the two peanut cultivars (Table 2), especially grains per spike had positive direct effect on grain yield (Khan et al., 2010). Also, 
grain weight per spike is very important yield components, which directly influence to yield and depends on grain number and grain chemical composition (Zecevic et al., 2010).

In regard to cropping systems, it is observed that fahl berseem was used as trap crop to capture left over $\mathrm{N}$ from the soil after peanut uprooting and improved total count of rhizobia that increased available soil $\mathrm{N}$ content and soil fertility. These results are in the same context with those by Baldwin (2006) who mentioned that from 40 to 75 percent of the total $\mathrm{N}$ contained in a legume cover crop is available in the soil for subsequent crops, depending on environmental conditions. He added that trap crops like small grains can be used to capture left over N from farm fields after a harvest of cash crops. Also, Pandey et al. (2008) concluded that massive loss of native soil $\mathrm{N}$ occurs in rice-wheat rotations when fields are left bare fallow during the dry-to-wet season transition period. Growing grain legumes and green manure crops during the transition season can immobilize soil $\mathrm{N}$ in the plant biomass in addition to adding $\mathrm{N}$ from the atmosphere. They added that reduced amounts of available soil $\mathrm{N}$ by growing crops during dry to wet season transition period result reduced $\mathrm{N}$ losses by both leaching and denitrification.

Significant increments in grain yield of wheat and its attributes under intensive cropping system can be attributed to the beneficial effect of nutrients released from the decomposition of the preceded legumes residues especially fahlberseem. Certainly, differences in genetic potential of these species played a major role in rooting pattern and $\mathrm{N}_{2}$-fixing capacity that led to a variation in BNF under sandy soil conditions. Using leguminous crop as fahl berseem during transition period between peanut and wheat added more $\mathrm{N}$ to the sandy soil than conventional cropping system (Table 1). In this concern, Hayat et al. (2008) showed that the variation in grain yield production between two legumes can be attributed to differences in genetic potential.

This improvement had a great ecological importance. It is expected that if such improvement continues unabated year after year, the overall situation will improve considerably within a few years. The variations in biomass production among the legumes crops can be attributed to differences in genetic potential, plant architecture, rooting pattern and $\mathrm{N}_{2}$-fixing capacity (Mandal et al., 1990). Exploitation of biological $\mathrm{N}$ is dependent on various factors like environment, nutritional status of soil and also the cropping pattern in use (Dakora \& Keya, 1997). When the plant dies, the fixed $\mathrm{N}$ is released; making it available to other plants and this helps to fertilize the soil (Postgate, 1988). It is evident from the data that intensive cropping system could be played a major role in improvement of nutritional status of the experimental soil than the other one. Growing fahl berseem after peanut led to increase in soil $\mathrm{N}$ availability for wheat growth and development that affected positively the yield attributes of wheat (Table 2). These results are in harmony with those obtained by Banziger et al. (1994) who indicated that increasing $\mathrm{N}$ application induced increasing leaf area, tiller formation and leaf area index. This resulted in producing more dry matter and grain yield. Also, Nawab et al. (2006) showed that the increase in wheat yield after mung bean may be due to $\mathrm{N}$ fixation by the previous legume crop. Though groundnut is a legume and can fix $\mathrm{N}$ but the yields of wheat following groundnut is lower, which may be due to the greater quantity of $\mathrm{Ca}$ absorbed by groundnut or due to allelopathic effect of groundnut on wheat.

With respect to the interaction, the results imply that peanut cultivars responded differently $(P \leq 0.05)$ to cropping systems for all studied traits except number of spikes $/ \mathrm{m}^{2}$.

\section{Conclusion}

According to results, it can be concluded that BNF by peanut cv. Ismailia 1 had significant effect on wheat grain yield per ha and this effect was increased by growing fahl berseem during transition period between peanut and wheat under sandy soil conditions. Also, intensive cropping system by using the local cultivar of peanut (Ismailia 1) was more profitable for Egyptian farmers.

\section{References}

A.O.A.C. (2000). Association of Official Agricultural Chemists Official Methods of Analysis.(15th A. O. A. C.), Washington, USA.

Abd El-Maksoud, M.F. (2008).Response of two peanut cultivars to row width and hill spaces in sandy soil.Research Journal of Agriculture and Biological Sciences, 4(5), 447-454.

Asfour, M.M., Abdalla, M.A., \&Essa, A.H.A. (2009).Response of three peanut cultivars to gypsum.Journal of Agricultural Sciences, Mansoura University, 34(9), 9577-9588.

Baldwin, K.R. (2006). Crop Rotations on Organic Farms.North Carolina Cooperative Extension Service.College of Agriculture and Life Sciences.NC State University.

Banziger, M., Feil, B.,\& Stamp, P. (1994).Competition between nitrogen accumulative and grain growth for 
carbohydrates during grain filling of wheat.Crop Science, 34, 440-446.http://dx.doi.org/10.2135/cropsci1994.0011183X003400020025x

Bulletin of Statistical Cost Production and Net Return.(2013).Summer and Nili Field Crops and Vegetables and Fruit. Agriculture Statistics and Economic Sector, Ministry of Egyptian Agriculture and Land Reclamation", Part (2), August 2013.

Bulletin of Statistical Cost Production and Net Return.(2014).Winter Field Crops and Vegetables and Fruit. Agriculture Statistics and Economic Sector, Ministry of Egyptian Agriculture and Land Reclamation", Part (1), February 2014.

Dakora, F.D., \& Keya, S.O. (1997).Contribution of legume nitrogen fixation to sustainable agriculture in $\begin{array}{lllll}\text { Sub-Saharan Africa.Soil Biology } & \text { 19-27. }\end{array}$ http://dx.doi.org/10.1016/S0038-0717(96)00225-8

Dinh, H.T., Kaewpradit, W., Jogloy, S., Vorasoot, N., \&Patanothai, A. (2013).Biological nitrogen fixation of peanut genotypes with different levels of drought tolerance under mid-season drought.SABRAO Journal of Breeding and Genetics, 45(3), 491-503.

El-Saady, A.M., El-Sayed, A.A., Teilep, W.M., \& El-Dahshouri, M.F. (2014).Response of some peanut (Arachishypogaea L.) cultivars grown in sandy soil to soil and foliar feeding with the different sources of phosphorus.International Journal of Plant and Soil Science, 3(6), 523-537. http://dx.doi.org/10.9734/IJPSS/2014/8089

Fageria, N.K., Baligar, V.C., \& Jones, C.A. (1997). Growth and mineral nutrition of field crop(2nd Edition). New York, USA: Marcel Dekker Inc.

Feil, B. (1997). The inverse yield-protein relationship in cereals: Possibilities and limitations for genetically improving the grain protein yield.Trends in Agronomy, 1, 103-119.

Freed, R.D. (1991).MSTATC Microcomputer Statistical Program.Michigan State University, East Lansing, Michigan, USA.

Gomez, K.A., \& Gomez, A.A. (1984).Statistical Procedures for Agricultural Research.(2nded.) Toronto, ON, Canada: John Willey and Sons.

Hardarson, G. (1993). Methods for enhancing symbiotic nitrogen fixation.Plant Soil, 152, 1-17.http://dx.doi.org/10.1007/BF00016329

Hayat, R., Ali, S., Siddique, M.T., \&Tahir, H.C. (2008). Biological nitrogen fixation of summer legumes and their residual effects on subsequent rainfed wheat yield.Pakistan Journal of Botany, 40(2), 711-722.

Khan, A.J., Azam, F., \& Ali, A. (2010).Relationship of morphological traits and grain yield in recombinant inbred wheat lines grown under drought conditions.Pakistan Journal of Botany, 42(1), 259-267.

Lindemann, W.C., \& Glover, C.R. (2013).Nitrogen Fixation by Legumes. The College of Agricultural, Consumer and Environmental Sciences on the World Wide Web at aces.nmsu.edu.

Liu, X. (2013).Cropping System in China (pp. 12-15). Beijing: Agricultural Press.

Mandal, B.J., Dhara, M.C., Mandal, B.B., Das, S.K.,\&Nandy, R. (1990).Rice, mung bean, soybean, peanut and black gram yields under different intercropping systems.Agronomy Journal, 82, 1063-1066.http://dx.doi.org/10.2134/agronj1990.00021962008200060006x

Myers, A. (1988). Cereal cropping.Plant and Soil, 174, 30-33.

Nambiar, P.C., \& Dart, P.J. (1983).Factors influencing nitrogenase activity (acetylene reduction) by root nodules of groundnut, Arachishypogaea L. Peanut Science, 10, 26-29.http://dx.doi.org/10.3146/i0095-3679-10-1-8

Nawab, K. H., Amanullah, M.A.,\& Ali, A. (2006).Response of wheat to farm yard manure, potassium and zinc under rainfed cropping patterns.Middle East Journal of Scientific Research, 1(1), 1-9.

O’Hara, G.W. (2001). Nutritional constraints on root nodule bacteria affecting symbiotic nitrogen fixation: a review.Australian Journal of Experimental Agriculture, 41, 417-433.http://dx.doi.org/10.1071/EA00087

Pandey, K.R., Shah, S.C., \& Becker, M. (2008).Management of native soil nitrogen for reducing nitrous oxide emissions and higher rice production.The Journal of Agriculture and Environment, 9, 1-9.

Phoomthaisong, J., Toomsan, B., Limpinuntana, V., Cadisch, G., \&Patanothai, A. (2003). Attributes affecting residual benefits of N2-fixing mung bean and groundnut cultivars.Biology and Fertility of Soils, 39(1), 
16-24.http://dx.doi.org/10.1007/s00374-003-0676-4

Pimratch, S., Jogloy, S., Toomsan, B., Jaisil, P., Sikhinarum, J., Kesmala, T.,\&Patanothai, A. (2004).Evaluation of seven peanut genotypes for nitrogen fixation and agronomic traits.Songklanakarin Journal of Science and Technology, 26(3), 295-304.

Postgate, J. (1998).Nitrogen Fixation.(3rded.) Cambridge University Press: Cambridge UK. Main website: WWW.CAMBRIDGEFORECAST.ORG

Shah, Z., Shah, S.H., Peoples, M.B., Schwenke, G.D., \&Hrridge, D.F. (2003). Crop residue and fertilizer N effects on nitrogen fixation and yields of legume-cereal rotations and soil organic fertility.Field Crops Research, 83, 1-11.http://dx.doi.org/10.1016/S0378-4290(03)00005-4

Shiferaw, B., Bantilan, M.C.S., \&Serraj, R. (2004).Harnessing the potential of BNF for Poor Farmers: Technological Policy and institutional constraints and research need.In R. Serraj(Ed.).Symbiotic Nitrogen Fixation; prospects for enhanced application in tropical agriculture (p. 3). New Delhi: Oxford \& IBH publishing Co. Pvt. Ltd.

Toomsan, B., McDonagh, J.F., Limpinuntana, V., \&Giller, K.E. (1995).Nitrogen fixation by groundnut and soyabean and residual nitrogen benefits to rice in farmers' fields in Northeast Thailand.Plant and soil, 175(1), 45-56.http://dx.doi.org/10.1007/BF02413009

Zecevic, V., Boskovic, J., Dimitrijevic, M.,\&Petrovic, S. (2010). Genetic and Phenotypic variability of yield components in wheat (TriticumaestivumL.).Bulgarian Journal of Agricultural Science, 16(4), 422-428.

\section{Copyrights}

Copyright for this article is retained by the author(s), with first publication rights granted to the journal.

This is an open-access article distributed under the terms and conditions of the Creative Commons Attribution license (http://creativecommons.org/licenses/by/3.0/). 